Anais da Academia Brasileira de Ciências (2006) 78(1): 113-121

(Annals of the Brazilian Academy of Sciences)

ISSN 0001-3765

www.scielo.br/aabc

\title{
Determinants of HIV-1 Mother-to-Child transmission in Southern Brazil
}

\author{
ANA M.B. MARTÍNEZ ${ }^{1 *}$, VANUSA P. DA HORA ${ }^{1 *}$, ADRIANA L. DOS SANTOS ${ }^{2 *}$, \\ RAUL MENDOZA-SASSI ${ }^{1}$, ANDRÉA VON GROLL ${ }^{1}$, ESMERALDA A.J.M. SOARES ${ }^{2}$, \\ NILDO D'ÁVILA ${ }^{1}$, JUSSARA SILVEIRA ${ }^{1}$, RENATA G. LEAL ${ }^{1}$, THE HIV/AIDS UNIT, \\ HU-FURG ${ }^{1}$, AMILCAR TANURI ${ }^{2}$ and MARCELO A. SOARES ${ }^{2}$ \\ ${ }^{1}$ Fundação Universidade Federal do Rio Grande, Rua General Osório s/n, 96200-190 Rio Grande, RS, Brasil \\ ${ }^{2}$ Laboratório de Virologia Molecular, Departamento de Genética, Universidade Federal do Rio de Janeiro, \\ CCS - Bloco A - sala A2-121, Cidade Universitária - Ilha do Fundão, 21944-970 Rio de Janeiro, RJ, Brasil \\ Manuscript received on March 16, 2005; accepted for publication on August 17, 2005; \\ presented by LuCIA MENDONÇA PREVIATO
}

\begin{abstract}
Different human immunodeficiency virus type 1 (HIV-1) subtypes may have distinct biological, immunological and pathogenic properties. Efficiency of mother-to-child transmission (MTCT) may be among those properties, but few and controversial results have been described so far. In this study, 102 children born from HIV-1-infected mothers between 1998 and 2004 in the city of Rio Grande, Brazil were analyzed for potential risk factors associated with MTCT. That geographic region is characterized by a high proportion of subtype C-infected subjects, and it allowed comparison between subtypes B and C and their influence on MTCT. The analysis also included clinical, obstetric and immunological parameters. Multivariate regression analyses were conducted to evaluate the influence of the parameters on MTCT, and prevalence ratios (PR) and $95 \%$ confidence intervals (CI95) were also calculated. A surprisingly high prevalence of subtype C of over 70\% was found. Only the HIV viral load and the use of ACTG 076 protocol were predictive of MTCT. HIV subtype and CD4 T-cell counts were not associated with increased risk of transmission. Although a clear expansion of subtype $\mathrm{C}$ is evident in southern Brazil, it does not seem to correlate with increased risk of vertical transmission.
\end{abstract}

Key words: HIV, MTCT, vertical transmission, subtype C, molecular epidemiology.

\section{INTRODUCTION}

Human immunodeficiency virus type 1 (HIV-1) can be divided in three major groups based on its genetic variability: $\mathrm{M}$ or main, $\mathrm{O}$ or outlier and $\mathrm{N}$ or new. Whereas groups $\mathrm{O}$ and $\mathrm{N}$ are of low prevalence and are restricted to certain areas of the African continent, group $\mathrm{M}$ is responsible for the

*All three authors equally contributed to this work.

Correspondence to: Marcelo A. Soares

E-mail: masoares@biologia.ufrj.br
AIDS pandemic (Peeters 2001). Spreading out of Africa, group $M$ viruses have evolved and dispersed in different lineages known as subtypes. Currently, nine subtypes and at least 16 recombinant circulating forms (CRFs) are distinctly recognized (Perrin et al. 2003), with distinct and dynamic prevalence distributions in different parts of the world. It is not known, however, whether those differences simply reflect historical and founder effects of the several HIV-1 subtypes, or if the dynamics of subtype- 
specific transmission potentials play a significant role (Kanki et al. 1999). An important example of such changes in HIV-1 subtype distributions includes the significant expansion of subtype $\mathrm{C}$ in southern and southeastern Africa, India and China (Novitsky et al. 2002). More than 90\% of new HIV-1 infections take place in Africa and Asia, where the epidemics is mainly driven by subtype C, and where over $25 \%$ of adults are infected in some of these countries (Essex 1999). Currently, subtype $\mathrm{C}$ is responsible for over $60 \%$ of the HIV-1 infections (Esparza and Bhamarapravati 2000).

In Brazil, the major circulating HIV-1 subtype is $\mathrm{B}$, although subtypes $\mathrm{C}, \mathrm{D}$ and $\mathrm{F}$ as well as diverse mosaic genomes have been described (Morgado et al. 1998, Martínez et al. 2002, Brindeiro et al. 2003, Soares et al. 2003). The city of Rio Grande, RS, situated in the extreme south of Brazil, is a harbor city with a great number of human interflows to and from Africa, Asia and Europe. In this sense, the role of immigrants in the introduction and prevalence of non-B subtypes of HIV-1 may be paramount (Perrin et al. 2003). In Rio Grande, although subtype $\mathrm{B}$ still predominates, subtype $\mathrm{C}$ was already responsible for $22 \%$ of the AIDS cases in 1997 (Martínez et al. 2002).

The biological and epidemiological implications of HIV-1 genetic variability remain to be elucidated. Some reports have suggested that different subtypes may have distinct biological features that would impact on the transmissibility and on disease progression in infected patients. CD4 T-cell counts were lower and HIV viral loads were higher in subtype C-infected than in subtype B-infected individuals (Neilson et al. 1999). Some reports have also tried to characterize maternal factors that may affect HIV-1 mother to child transmission (MTCT) in African pregnant women (Bobat et al. 1996). Among those factors, different genotypes could be associated to a higher risk of transmission (Renjufi et al. 2001). On the other hand, other investigators have found that although low CD4 and high viral loads were predictive of MTCT, no association with HIV-1 subtype was observed (Tranchat et al. 1999,
Guevara et al. 2002, Tapia et al. 2003, Renjufi et al. 2003). Therefore, observations in this issue have not been consistent. Obstetric factors as type of delivery, time of membrane rupture and birth weight, and the use of ACTG 076 protocol during pregnancy and delivery, have been identified as risk factors for MTCT (Fawzi et al. 2001, Zijenah et al. 2004).

The present study assessed the prevalence of subtype C of HIV-1 in the city of Rio Grande, RS, Brazil, through the epidemiological and molecular analysis of HIV-1-positive pregnant women attending the AIDS service of Rio Grande University Hospital (HU/FURG). MTCT patterns were also evaluated according to HIV-1 subtype and other hostrelated factors of the infected mothers.

\section{MATERIALS AND METHODS}

Population, SAMPles AND VARiables

This cross-sectional study included HIV-1-positive mothers that attended the AIDS service of HU/ FURG from 1998 to June 2004 and their newborn children. Clinical data were obtained from their follow-up medical records. The study was submitted and approved by the research ethic committee of the institution.

The infant HIV infection status was defined as positive, according to guidelines of the Brazilian Ministry of Health, if the individual presented two consecutive tests with detectable viral load or two positive serological tests and a confirmatory indirect immunofluorescence test by 18 months of age. Since 1998 every pregnant woman that attended the institution was tested for HIV-AIDS as recommended by the health authorities.

The independent variables studied were:

a) mother HIV-1 subtype, determined as described below and exposed mothers were defined as those infected with subtype C;

b) use of AIDS Clinical Trial Group (ACTG) 076 protocol;

c) $\log _{10}$ HIV viral load (VL) of the mother in the last three months of pregnancy; 
d) CD4 T-cell counts of the mother in the last three months of pregnancy;

e) type of delivery;

f) time of membrane rupture (less than two hours/ two hours or more);

g) children weight at birth.

Use of ACTG 076 was categorized as a) complete: when the mother received zidovudine during pregnancy and at labor, as well the newborn; $b$ ) incomplete: when at least one of the three situations where accomplished; c) null: when no zidovudine was taken by the mother and the infant.

Blood Collection And HIV-1 Subtype DeterMINATION

Ten milliliters of whole blood were collected from each patient. Fifty microliters were used for CD4 T-cell counts by flow cytometry in a FACSCount apparatus (Becton \& Dickinson, Franklin Lakes, NJ) according to the manufacturer's specifications. Five milliliters were used for HIV-1 VL determination by the branched-DNA technique (Quantiplex TM bDNA 340, Bayer, Leverkusen, Germany), also as recommended by the producer. The remaining blood was used for PBMC DNA extraction as described below.

\section{HIV-1 SUbTYPE DETERMINATION}

Approximately $5 \mathrm{ml}$ of whole blood was used for peripheral blood mononuclear cell (PBMC) extraction. PBMC were isolated by centrifugation in Ficoll-Hypaque (Amersham, Uppsala, Sweden), washed in PBS and then lysed in $200 \mu 1$ of lysis buffer (TE pH 8.1, $0.001 \%$ Triton X-100, 0.001\% SDS). Fifty micrograms of proteinase $\mathrm{K}$ were added to each sample and the proteolysis was carried out at $56^{\circ} \mathrm{C}$ for $1 \mathrm{~h}$. Proteinase $\mathrm{K}$ was inactivated at $95^{\circ} \mathrm{C}$ for $10 \mathrm{~min}$.

env gene fragments corresponding to the IDR domain of gp41 were amplified in nested PCR reactions using genomic DNA as template. The primers used were JH41F (5'CAG CAG GWA GCA CKA TGG G 3') and JH38R (5'GGT GAR TAT
CCC TKC CTA AC 3') (outer), and ENV27F (5'CTG GYA TAG TGC ARC ARC A 3') and MENV19R (5'AAR CCT CCT ACT ATC ATT ATR A 3') (inner). PCR amplifications were conducted in $50 \mu 1$ reaction volumes containing $10 \mathrm{X}$ Taq reaction buffer, $0.2 \mathrm{mM}$ of each dNTP, $2.5 \mathrm{mM} \mathrm{MgCl}_{2}$, $12.5 \mathrm{pmol}$ of each respective primer and $1.25 \mathrm{U}$ of Taq polymerase. Reactions were carried out under the following conditions: one initial denaturing cycle of $3 \mathrm{~min}$ at $95^{\circ} \mathrm{C}, 1 \mathrm{~min}$ at $56^{\circ} \mathrm{C}$ and $1 \mathrm{~min}$ at $72^{\circ} \mathrm{C}$, followed by 35 cycles of $30 \mathrm{sec}$ at $95^{\circ} \mathrm{C}$, $45 \mathrm{sec}$ at $55^{\circ} \mathrm{C}$ and $1 \mathrm{~min}$ at $72^{\circ} \mathrm{C}$. A final extension step of $7 \mathrm{~min}$ at $72^{\circ} \mathrm{C}$ was conducted to complete all unfinished PCR products. Inner reactions were carried out under the same conditions, with the exception of the annealing temperature, which was of $56^{\circ} \mathrm{C}$. All reactions were carried out in a 9700 DNA thermal cycler (Applied Biosystems, Foster City, CA). Generated PCR products were purified with the Concert Rapid PCR Purification System kit (Invitrogen, Carlsbad, CA) according to the manufacturer's recommendations, and analyzed in a $1 \%$ agarose gel. DNA products were quantified using the DNA mass ladder (Invitrogen), and $100 \mathrm{ng}$ were used in sequencing reactions with the same primers used in PCR. Reactions were conducted with the BigDye Terminator Cycle Sequencing Reaction kit v.3.0 (Applied Biosystems), and were run in an ABI 3100 Genetic Analyzer apparatus (Applied Biosystems).

Sequences in electronic format were edited in the software SeqMan of the LaserGene package (DNAStar Inc., Madison, WI), and then aligned in ClustalW (Thompson et al. 1994). HIV-1 subtype determination was conducted by aligning query sequences with an HIV-1 subtype reference set obtained at the Los Alamos National Laboratory HIV Database (http://hiv-web.lanl.gov). Phylogenetic analysis using the neighbor-joining method and the Kimura two-parameter correction was conducted with all sequences, and samples were assigned a specific subtype when they grouped with reference sequences from a specific HIV-1 clade. The inference was calculated in the program MEGA 2.0 (Kumar 
et at. 2001), and phylogenetic trees were drawn in TreeView (Page 1996). The robustness of the different clades in the tree was assessed by bootstrap with 2,000 replicates under MEGA.

\section{Statistical ANALYSES}

Statistical evaluations were conducted in the package Stata 8.0 (Stata Corp., College Station, TX). Firstly, a descriptive analysis was conducted, where averages and standard deviations were calculated for the numeric variables and the proportions for the categorized variables. Secondly, bivariate analyses were carried out to assess the association between child HIV status and the several studied factors. This was done by calculating the prevalence ratios (PR) and their respective $95 \%$ confidence intervals $\left(\mathrm{CI}_{95}\right)$. In these analyses the chi-square test was used. Finally, a multivariate analysis was conducted between the child HIV status and the diverse associated risk factors adjusted to each other. A backward Poisson regression was used for this. The variables that had a $p$-value lower than 0.05 were kept in the model. The adjusted PR and $\mathrm{CI}_{95}$ were then recalculated. The significance of the models was assessed by the Wald test. A 0.05 two-tailed level of significance was applied to all statistical evaluations.

\section{Sequence Data}

All env gp41 IDR and gp120 sequences were submitted to GenBank and were assigned the accession numbers AY621381 through AY621463.

\section{RESULTS}

\section{Characteristics of THE STUdied SAMPLES}

In the studied period a total of 102 children were born from HIV-infected mothers and enrolled. The average age of the mothers was 25.86 years (SD 5.96). Fifty three percent of the children were males. Seventy two percent of the mothers were infected by subtype $\mathrm{C}$ viruses. Twelve (11.8\%) newborns were HIV-1-positive, slightly over half of the mothers (52.6\%) had CD4 T-cell counts between 200 and 499 cells $/ \mathrm{mm}^{3}$ of blood (CDC immunological stage
B), and $47.3 \%$ had a $\log _{10}$ HIV VL between 4 and 5 . The average CD4 T-cell count was 403.8 cells $/ \mathrm{mm}^{3}$ (SD 226) and the $\log _{10}$ HIV VL was 3.2 (SD 1.8). Other characteristics of the studied samples are depicted in Table I.

\section{RISK FACTORS FOR MTCT}

Prevalence ratio adjusted values can be observed for all studied models in Table II. The $\log _{10}$ HIV VL was a risk factor for mother-to-child transmission. Each log increased the risk of transmission in more than seven hundred percent. Use of ACTG 076 protocol was associated with the HIV status of the child, and a linear trend was detected between the three studied categories. Those with complete protocol had a $99 \%$ reduction compared to the null protocol category. All other factors had lost their effect or drastically diminished their PR when adjusted to each other, and thus could not be considered MTCT predictors. CD4 T cell counts, which had shown a $p$-value $=0.02$ in the bivariate analysis, had their PR significantly reduced and their $p$-values increased when adjusted to other factors.

\section{DISCUSSION}

The present study analyzed the effect of several putative risk factors on vertical transmission of HIV-1 in Southern Brazil. We have found that the $\log _{10}$ HIV VL was the best predictor of MTCT, and that each unit increase corresponded to an increase in risk for transmission of 8.5 times. This result is consistent with the findings by several groups (Kamara et al. 2005, Magder et al. 2005, Guevara et al. 2002, Katzenstein et al. 1999, Garcia et al. 1999, Fawzi et al. 2001, Blackard et al. 2001). In contrast to that, Tranchat et al. (1999) found no significant association between maternal HIV VL and vertical transmission. The reasons for the discordant results remain to be elucidated, but they might be associated with the low statistical power of small samples which are characteristic of those studies. For CD4 T-cell counts, we found no significant association. This result is in agreement with that of Katzenstein et al. (1999), whereas other studies have found an 
TABLE I

HIV-1 subtype and maternal and infant characteristics of the studied cohort $(n=102)$.

\begin{tabular}{|c|c|c|c|}
\hline Characteristic & $\begin{array}{l}\text { Sample } \\
\mathrm{n}(\%)\end{array}$ & $\begin{array}{c}\text { Transmitting } \\
\text { mothers } \mathrm{n}(\%)\end{array}$ & $\begin{array}{l}\text { Non-transmitting } \\
\text { mothers } \mathrm{n}(\%)\end{array}$ \\
\hline \multicolumn{4}{|l|}{ Infant HIV status (n, \%) } \\
\hline Negative & $90(88.2)$ & - & - \\
\hline Positive & $12(11.8)$ & - & - \\
\hline \multicolumn{4}{|l|}{ Time of membrane rupture $(n, \%)$} \\
\hline$<2$ hours & $81(79.4)$ & $10(12.3)$ & $71(87.7)$ \\
\hline$\geq 2$ hours & $21(20.6)$ & $2(9.5)$ & $19(90.5)$ \\
\hline \multicolumn{4}{|l|}{ Delivery $(n, \%)$} \\
\hline Cesarian & $39(38.2)$ & $4(10.3)$ & $35(89.7)$ \\
\hline Vaginal & $63(61.8)$ & $8(12.7)$ & $55(87.3)$ \\
\hline Weight at birth (mean, SD) & $2940.7(536.6)$ & $2856.7(406.9)$ & $2952.8(553.0)$ \\
\hline \multicolumn{4}{|c|}{ Mother Infecting HIV-1 Subtype (n, \%) } \\
\hline $\mathrm{B}$ & $28(27.5)$ & $2(7.1)$ & $26(92.9)$ \\
\hline $\mathrm{C}$ & $74(72.5)$ & $10(13.5)$ & $64(86.5)$ \\
\hline \multicolumn{4}{|l|}{ Use of ACTG $076(n, \%)$} \\
\hline Null & $7(6.8)$ & $5(71.4)$ & $2(28.6)$ \\
\hline Incomplete & $33(32.4)$ & $6(18.2)$ & $27(81.8)$ \\
\hline Complete & $62(60.8)$ & $1(1.6)$ & $61(8.4)$ \\
\hline \multicolumn{4}{|l|}{ CD4 T-cell counts $(n, \%)$} \\
\hline $0-199$ & $18(19.0)$ & $4(22.2)$ & $14(78.8)$ \\
\hline $200-499$ & $50(52.6)$ & $3(6.0)$ & $47(94.0)$ \\
\hline$\geq 500$ & $27(28.4)$ & $0(0.0)$ & $27.0(100.0)$ \\
\hline CD4 T-cell (mean, SD) & $403.8(226.0)$ & $231.4(152.5)$ & $417.5(225.9)$ \\
\hline \multicolumn{4}{|l|}{$\log _{10}$ HIV viral load } \\
\hline $0-2.99$ & $27(28.4)$ & $0(0.0)$ & $27(100.0)$ \\
\hline $3-3.99$ & $23(24.2)$ & $0(0.0)$ & $23(100.0)$ \\
\hline $4-4.99$ & $35(36.8)$ & $2(5.7)$ & $33(94.3)$ \\
\hline$\geq 5$ & $10(10.5)$ & $5(50.0)$ & $5(50.0)$ \\
\hline $\log _{10}$ HIV viral load (mean, SD) & $3.2(1.8)$ & $5.2(0.6)$ & $3.1(1.8)$ \\
\hline \multicolumn{4}{|l|}{ Infant HIV status (n, \%) } \\
\hline Negative & $90(88.2)$ & - & - \\
\hline Positive & $12(11.8)$ & - & - \\
\hline
\end{tabular}

association between CD4 counts and MTCT (Renjufi et al. 2001, Tranchat et al. 1999).

Another important finding was the effect of ACTG 076 protocol, which reduced the risk of transmission. A clear dose-response relation was found between categories, and those who had an incomplete treatment had an intermediate risk, when compared with those under no treatment. A conspicuous reduction was observed when mother and child are treated. Magder et al. (2005) have also found a neg- 
TABLE II

Bivariate and multivariate-adjusted prevalence ratios (PR) for HIV-1-positive infant status and risk factors.

\begin{tabular}{|c|c|c|c|c|c|}
\hline Risk Factor & $\begin{array}{l}\text { Prevalence } \\
\text { (n) }\end{array}$ & $\begin{array}{c}\text { Bivariate PR } \\
(95 \% \mathrm{CI})\end{array}$ & $p$-value & $\begin{array}{l}\text { Multivariate PR } \\
\qquad(95 \% \mathrm{CI})\end{array}$ & $p$-value \\
\hline $\begin{array}{l}\text { Maternal CD4 T cell } \\
\text { counts }\left(\text { cells } / \mathrm{mm}^{3}\right)\end{array}$ & & $\begin{array}{c}1 \\
0.20(0.05-0.75)\end{array}$ & 0.02 & $\begin{array}{c}1 \\
0.99(0.99-1.99)^{a}\end{array}$ & 0.3 \\
\hline $\begin{array}{l}\text { Time of membrane rupture } \\
\text { At delivery } \\
\text { Before delivery }\end{array}$ & $\begin{array}{l}12.9(10) \\
9.52(2)\end{array}$ & $\begin{array}{c}1 \\
0.7(0.16-3.34)\end{array}$ & 0.7 & $\begin{array}{c}1 \\
8.89(0.28-2.84)^{b}\end{array}$ & 0.2 \\
\hline Weight at birth & & $0.99(0.99-1.00)$ & 0.6 & $0.99(0.99-100)^{c}$ & 0.2 \\
\hline $\begin{array}{l}\text { Delivery } \\
\text { Cesarian } \\
\text { Vaginal }\end{array}$ & $\begin{array}{l}11.1(4) \\
12.9(8)\end{array}$ & $\begin{array}{c}1 \\
1.16(0.35-3.85)\end{array}$ & 0.8 & $\begin{array}{c}1 \\
0.22(0.01-3.02)^{d}\end{array}$ & 0.3 \\
\hline $\begin{array}{l}\text { Maternal Subtype } \\
\text { B } \\
\text { C }\end{array}$ & $\begin{array}{c}7.14(2) \\
14.29(10)\end{array}$ & $\begin{array}{c}1 \\
2(0.44-9.13)\end{array}$ & 0.4 & $\begin{array}{c}1 \\
2.10(0.24-18.2)^{e}\end{array}$ & 0.5 \\
\hline $\begin{array}{l}\text { ACTG } 076 \\
\text { Null } \\
\text { Incomplete } \\
\text { Complete }\end{array}$ & $\begin{array}{l}71.4(5) \\
18.8(6) \\
1.7(1)\end{array}$ & $\begin{array}{c}1 \\
0.26(0.08-0.86) \\
0.02(0.002-0.20)\end{array}$ & 0.001 & $\begin{array}{c}1 \\
0.02(0.000-0.47)^{f} \\
0.008(0.00-0.22)\end{array}$ & $0.05 *$ \\
\hline HIV $\log _{10}$ VL $\left(1 \log _{10}\right)$ & & $8.53(2.28-31.96)$ & 0.001 & $8.53(2.38-31.96)^{f}$ & 0.001 \\
\hline
\end{tabular}

${ }^{a}$ Model adjusted to maternal CD4 counts, time of membrane rupture, weight at birth, type of delivery, maternal subtype, ACTG 076, and HIV viral load ( $\mathrm{n}=92)$; ${ }^{b}$ Model A minus maternal CD4 counts ( $\left.\mathrm{n}=92\right) ; \quad{ }^{c}$ Model B minus time of membrane rupture (n=92); ${ }^{d}$ Model $\mathrm{C}$ minus weight at birth (n=95); ${ }^{e}$ Model D minus type of delivery (n=95); ${ }^{f}$ Final Model, PACTG 76 and HIV viral load (n=95); *p-value for linear trend.

ative association between antiretroviral therapy and vertical transmission.

In regard to the prevalence of subtype $\mathrm{C}$, our group has reported that this subtype represented $22 \%$ of the samples in 1997 (Martínez et al. 2002). In this study, seven years later, a subtype $\mathrm{C}$ prevalence was found over $70 \%$. Therefore, the increase of subtype $\mathrm{C}$ is evident in this part of Brazil. Similar subtype $\mathrm{C}$ dissemination has been reported in Southern and Eastern Africa, regions where the HIV/AIDS epidemic affects a large portion of the population (Peeters 2001, Perrin et al. 2003).

There was no association in our study between infecting HIV-1 subtype and increased risk for MTCT. This is in agreement with data by Tranchat et al. (1999), Murray et al. (2000) and Tapia et al.
(2003). Other studies, however, did find a relationship between subtype and MTCT, mostly in Africa where a variety of subtypes exists (Blackard et al. 2000, Yang et al. 2004, Renjufi et al. 2004). It is important to note, however, that the HIV-1 subtypes compared in those studies did not include subtype $\mathrm{B}$, and thus further differences in MTCT might still be of importance.

Obstetric factors are also considered a risk factor of MTCT. Some studies have found no association (Renjufi et al. 2004, Yang et al. 2004), while others have (Zijenah et al. 2004). Fawzi et al. (2001) detected an association between prematurity and transmission, but did not find it for time of membrane rupture.

In this study, neither the type of delivery, time 
of membrane rupture, nor birth weight were associated with HIV transmission. However, only two newborns were positive in the $\geq 2 \mathrm{~h}$ membrane rupture group. Therefore, the possibility of lack of power must be considered. Another explanation for the absence of association between vertical transmission and obstetric factors in this study may be the described association between HIV subtype C and in-utero transmission (Renjufi et al. 2004). As it has been reported in this study most of the positive cases were with subtype $\mathrm{C}$, masking the effect of time of membrane rupture and type of delivery. Under such scenario, specific and fast-acting MTCT prevention programs should take place in southern Brazil, where the prevalence of subtype $\mathrm{C}$ is high (Soares et al. 2003, Martínez et al. 2002).

In summary, this study has shown that the most important factors involved in MTCT are maternal HIV viral load and the use of ACTG 076 protocol. Although the expansion of HIV-1 subtype $\mathrm{C}$ in southern Brazil highlights the importance of monitoring the dynamics of the HIV/AIDS epidemic in that part of the country, the infection with this subtype does not seem to have an increased risk of MTCT.

\section{ACKNOWLEDGMENTS}

We are in profound debt to members of HIV/AIDS Unit of the Rio Grande University for helping with clinical follow-up of pregnant mothers and their newborns. We would also like to thank Adriana O. Afonso for helping with sample processing. We also wish to thank Drs. C.S. Moss, D.R. Mendoza and M. Gonzaga from the HIV/AIDS Unit for their contribution to this work. This work was supported by Universidade Federal do Rio de Janeiro/UFRJ and by The Brazilian Federal Government Health Department.

\section{RESUMO}

Diferentes subtipos do virus da imunodeficiência humana do tipo 1 (HIV-1) podem ter propriedades biológicas, imunológicas e patogênicas distintas. A eficiência da trans- missão materno-infantil (TMI) pode estar entre estas propriedades, porém resultados escassos e controversos foram descritos até o momento. Neste estudo, 102 crianças nascidas de mães infectadas pelo HIV-1 entre 1998 e 2004 na cidade do Rio Grande, Brasil, foram analisadas para fatores de risco potenciais associados à TMI. Aquela região geográfica é caracterizada por uma alta proporção de indivíduos infectados pelo subtipo C do HIV-1, permitindo a comparação entre os subtipos B e C e sua influência na transmissão vertical do vírus. A análise também incluiu parâmetros clínicos, obstétricos e imunológicos. Análises de regressão multivariada foram conduzidas para avaliar a influência daqueles parâmetros na TMI, e as razões de prevalência (RP) e intervalos de confiança de 95\% (IC95) foram também calculados. Um prevalência surpreendentemente alta do subtipo $\mathrm{C}$ acima dos $70 \%$ foi encontrada. Somente a carga viral do HIV e o uso de protocolo ACGT 076 maternos forma preditivos de TMI. O subtipo do HIV-1 e a contagem de células T CD4+ não foram associados a um risco aumentado de transmissão. Embora uma clara expansão do subtipo $\mathrm{C}$ seja evidente no sul do Brasil, esta não parece estar correlacionada com risco aumentado de transmissão vertical.

Palavras-chave: HIV, transmissão materno-infantil, transmissão vertical, subtipo $\mathrm{C}$, epidemiologia molecular.

\section{REFERENCES}

Blackard J, Renjufi B, Chaplin B, Msamanga G, FAwZI W AND EsseX M. 2000. Diversity of the HIV-1 long terminal repeat following mother-tochild transmission. Virology 274: 402-411.

BLACKARD JT ET AL. 2001. HIV-1 LTR subtype and perinatal transmission. Virology 287: 261-265.

Bobat R, CoOvadia H, Coustsoudis A And Moodley D. 1996. Determinants of mother-tochild transmission of human immunodeficiency virus type 1 infection in a cohort from Durban, South Africa. Pediatr Infect Dis J 15: 604-610.

BRINDEIRO RM ET AL. 2003. Brazilian Network for HIV Drug Resistance Surveillance (HIV-BResNet): a survey of chronically infected individuals. AIDS 17: 1063-1069.

ESPARZA J AND BHAMARAPRAVATI N. 2000. Acceler- 
ating the development and future availability of HIV1 vaccines: why, when, and how. Lancet 355: 20612066.

ESSEX M. 1999. Human immunodeficiency viruses in the developing world. Adv Virus Res 53: 71-88.

FAWZi W, MSAmanga G, RENJUfi B, SPIEgElman D, Urassa E, Hashemi L, Antelman G, EsSEX M AND Hunter D. 2001. Predictors of intrauterine and intrapartum transmission of HIV-1 among Tanzanian women. AIDS 15: 1157-1165.

Garcia PM ET AL. 1999. Maternal levels of plasma human immunodeficiency virus type 1 RNA and the risk of perinatal transmission. N Engl J Med 341: 394-402.

Guevara H, Casseb J, Zijenah LS, Mbizvo M, OCEGUERA 3RD LF, HANSON CV, KATZENSTEIN DA AND HENDRY RM. 2002. Maternal HIV-1 antibody and vertical transmission in subtype $\mathrm{C}$ virus infection. J Acquir Immune Defic Syndr 29: 435440 .

Kamara P, Melendez-Guerrero LM, Arroyo M, Weiss HL AND Jolly PE. 2005. Maternal plasma viral load and neutralizing/enhancing antibodies in vertical transmission of HIV: A nonrandomized prospective study. Virology J 2: 15.

KANKI PJ ET AL. 1999. Human immunodeficiency virus type 1 subtypes differ in disease progression. $\mathrm{J}$ Infect Dis 179: 68-73.

Katzenstein DA, Mbizvo M, Zijenah L, Gittens T, Munjoma M, Hill D, Madzime S And MaLDONADO Y. 1999. Serum level of maternal human immunodeficiency virus (HIV) RNA, infant mortality, and vertical transmission of HIV in Zimbabwe. J Infect Dis 179: 1382-1387.

Kumar S, Tamura K, Jakobsen IB and Nei M. 2001. MEGA2: molecular evolutionary genetics analysis software. Bioinformatics 17: 1244-1245.

Magder LS, Mofenson L, PAUl ME, Zorrilla CD, Blattner WA, TuOMala RE, LARussa P, LANDESMAN S AND RICH KC. 2005. Risk factors for in utero and intrapartum transmission of HIV. J Acquir Immune Defic Syndr 38: 87-95.

Martínez AM, BARbosa EF, FERreira PC, CARdoso FA, Silveira J, SAssi G, DA Silva CM, MendoncA-Signorini V And Antunes CM. 2002. Molecular epidemiology of HIV-1 in Rio
Grande, RS, Brazil. Rev Soc Bras Med Trop 35: 471-476.

Morgado MG ET AL. 1998. Molecular epidemiology of HIV-1 in Brazil: high prevalence of HIV-1 subtype $B$ and identification of an HIV-1 subtype D infection in the city of Rio de Janeiro, Brazil. Evandro Chagas Hospital AIDS Clinical Research Group. J Acquir Immune Defic Syndr Hum Retrovirol 18: 488-494.

Murray MC, Embree JE, Ramdahin SG, ANZALA AO, Nuenga S And Plummer FA. 2000. Effect of human immunodeficiency virus (HIV) type 1 viral genotype on mother-to-child transmission of HIV-1. J Infec Dis 181: 746-749.

NeILSON JR ET AL. 1999. Subtypes of human immunodeficiency virus type 1 and disease stage among women in Nairobi, Kenya. J Virol 73: 4393-4403.

NOVITSKY V ET AL. 2002. Human immunodeficiency virus type 1 subtype $\mathrm{C}$ molecular phylogeny: consensus sequence for na AIDS vaccine design? J Virol 76: 5435-5451.

PAGE RD. 1996. TreeView: an application to display phylogenetic trees on personal computers. Comput Appl Biosci 12: 357-358.

Peeters M. 2001. The genetic variability of HIV-1 and its implications. Tranfus Clin Biol 8: 222-225.

Perrin L, Kaiser L And Yerly S. 2003. Travel and the spread of HIV-1 genetic variants. Lancet Infec Dis 3: 22-27.

RENJUFI B ET AL. 2001. Differences in perinatal transmission among human immunodeficiency virus type 1 genotypes. J Hum Virol 4: 16-25.

Renjufi B, Chung M, Gilbert P, Mwakagile D, MSAmanga G, FAWZI W AND EsSEX M. 2003. In-utero transmission of quasispecies among human immunodeficiency virus type 1 genotypes. Virology 307: 278-282.

Renjufi B, Gilbert P, Chaplin B, Msamanga G, Mwakagile D, Fawzi W, Essex M and TaNZANIAN VitAMIN AND HIV STUdy GROUP. 2004. Preferential in-utero transmision of HIV-1 subtype $\mathrm{C}$ as compared to HIV-1 subtype A or D. AIDS 18: 1629-1636.

SOARES MA ET AL. 2003. A specific subtype C of human immunodeficiency virus type 1 circulates in Brazil. AIDS 17: 11-21. 
Tapia N, Franco S, Puig-Basagoiti F, Menendez C, Alonso Pl, Mshinda H, Clotet B, Saiz JC AND MARTINEZ MA. 2003. Influence of human immunodeficiency virus type 1 subtype on motherto-child transmission. J Gen Virol 84: 607-613.

ThOMPSON JD, Higgins DG AND GIBSON TJ. 1994. CLUSTAL W: improving the sensitivity of progressive multiple sequence alignment through sequence weighting, position-specific gap penalties and weight matrix choice. Nucleic Acids Res 22: 4673-4680.

Tranchat C, Van de Perre P, Simonon-Sorel A, Karita E, Benchaib M, Lepage P, DesGRANGes C, Boyer V AND TREPo C. 1999. Maternal humoral factors associated with perinatal human immunodeficiency virus type- 1 transmission in a cohort from Kigali, Rwanda, 1988-1994. J Infect 39: 213-220.
YANG C, Li M, SHI YP, WinTER J, VAN EIJK AM, Ayisi J, Hu DJ, STeKetee R, NAhLen BL AND LAL RB. 2004. Genetic diversity and high proportion of intersubtype recombinants among HIV type 1infected pregnant women in Kisumu, western Kenya. AIDS Res Hum Retroviruses 20: 565-574.

ZiJENAH LS ET AL. 2004. Timing of mother-to-child transmission of HIV-1 and infant mortality in the first 6 months of life in Harare, Zimbabwe. AIDS 18: 273-280. 